\title{
Tragedy, Modernity and Political Life
}

\author{
Thomas Osborne ${ }^{1}$
}

Accepted: 21 October 2021/ Published online: 10 November 2021

(c) The Author(s) 2021

\begin{abstract}
What are the links between tragedy, politics and modernity? Diverse currents in social and critical theory have tackled this question; some arguing that modernity has itself a tragic structure insofar as its promises are undermined by their own realisation, others that the diversity of worldviews (the 'warring Gods' referred to by Max Weber) has tragic_-because unreconcilable-form. After briefly reviewing some of these issues, the paper looks more specifically at tragic structure in relation to (European) modernity and political reason. The French Terror has unique significance in this context, signalling as it does the failure of any kind of political rationality that seeks to take unmediated, universal form. The consequences of this failure are also, in a way, tragic in so far as they involve contradictions and irresolvable dilemmas of ongoing, everyday political existence. As a result—and perhaps this should itself be seen as much in terms of tragedy as triumphalism—our modernity condemns us to liberalism.
\end{abstract}

Keywords Liberalism · Political reason · Terror $\cdot$ Tragedy $\cdot$ Modernity

The term 'tragedy' has a wide and sometimes rather contradictory semantic reach and a complex relation to the history of social and critical—and political—theory. At its simplest, it can simply mean something like bad or awful things that happen (tsunamis and genocides are tragedies); sometimes, it can mean bad things that happen that specifically are tragedies because they were not necessary but eminently avoidable—genocides again, the New Orleans tragedy after Hurricane Katrina, or the Grenfell fire. In contrast, perhaps the most specific — and most interesting — notion of tragedy affirms it not as something tragic because unnecessary but precisely as bound up with necessity; as something awful that has happened that was in a sense nonetheless necessary or at least inevitable (Cavell 1979, p. 377).

This notion of tragedy as necessity is close to what we so often find in classical Greek Tragedy, generally taken as the original paradigm of all recourse to the tragic. Here tragedy can mean not just bad things that happen but something like the outcome of a conflict of necessities. The paradigm of such a conflict might be that of Antigone, faced with the dual necessity of honouring the laws and doing her duty by

Thomas Osborne

thomas.osborne@bristol.ac.uk

1 SPAIS, University of Bristol, 11 Priory Road, Bristol BS8 1TU, UK burying her brother (Shklar 2019, lecture 2). What is tragic about Antigone's situation (at least in Sophocles's version) is not that she does the good thing-burying her brother's corpse - and that Creon, the king, does the bad thing by condemning her to death for doing so. Creon and Antigone both, essentially, do the right thing, which is necessary for them. She must bury her brother, and he must affirm the laws of the city by condemning her for doing so. Both are enmeshed in the tragic situation that is presented by the drama; it is everyone's tragedy or at least the city's tragedy, not just Antigone's.

This sort of tragedy does not take a straightforward moral stance towards its subject matter, and this indeed may be its use-value, that it avoids the easy—good/bad—dichotomies of obligations either met or evaded that characterise what Bernard Williams called the 'morality system' (Williams 1985, pp. 174-175). An agent embroiled in a tragic situation might perhaps experience regret and even possibly shame, but not necessarily guilt as such (Williams 1995a). Perhaps the agent could have done nothing else. On the other hand, in a Greek tragic structure such as that of Oedipus, there is guilt, but it is anonymous or, as it were, generalised guilt. Oedipus knows by the end that he has been responsible for the degradation of Thebes and he does feel guilty for that, but it is not personal guilt that he could have avoided by different actions. What is tragic is not that this or that actor 
behaved in this or that way but that they had no choice but to act in this way even though it might be detrimental, to say the least, both to them and to others.

\section{Max Weber and the Tragic}

Now, in what is of course a very different idiom, modern social theory (and its variants) has frequently, perhaps constitutively, found itself confronting just these kinds of rival necessity.

Social theory (and the kinds of philosophy associated with it) has tended to explore the conditions of modernity in the context not least of its ironic implications: the theme for instance of the tragedy of technology, made famous by Heidegger; the irony of technology being that although technology confers benefits it also imposes limits (Heidegger 2013). There is a later version too, albeit with a very different tone, in Ulrich Beck's concept of the risk society (Beck 1992); the idea that progress, technological emancipation-enlightened modernity in short-also carries inevitable costs that are integral and not merely incidental to it and which in fact link to it with a sort of amplification effect. This, then, is a version of the clash of necessities: technology is emancipating but also limiting, even enslaving. No doubt Dialectic of Enlightenment would also come under this heading, as could the work of the Frankfurt School more generally (Adorno and Horkheimer 1944; cf. Connerton 1980); and as would the work of Max Weber on legal-rational domination and bureaucracy. Hence, we get the tragic irony of the famous 'iron cage' of The Protestant Ethic of 1905. Weber's logic here is precisely to do with necessity (albeit arising from what was basically a kind of accident); however, we brought this about, now we cannot escape from it. 'The Puritan wanted to work in a calling; we are forced to do so' (Weber 1992, p. 181). In this sense, modernity is both necessary (inevitable) yet, to some considerable extent, unfortunate. Weber himself recognised the antinomies of modernity whilst seeking to live up to them rather than retreat from them.

But there are at least three versions of the tragic theory of modernity in Weber, and what they represent is more a mosaic than a process. Aside from the irony-of-bureaucracy version well known to students of sociology, there is - very closely related to it - the irony-of-secularisation (or rather, the Entzauberung) version. This is the famous disenchantment of the world; that in our modernity we have made no room for God but on the other hand we have lost our ethical orientations and feel for values as a result (Weber 1991a, p. 155). Then, somewhat differently, yet equally ironic in the sense of equally inevitable, there is the value-sphere version. Weber's great essay on 'The Religious Rejections of the World and their Directions', first published in the Archiv fur Sozialwissenchaft und Sozialpolik in 1915, has a different emphasis from the well-known thesis about the ironies of bureaucracy (Weber 1991b). It is that the warring gods have returned; that we are faced with differing and irreducible life orders-art, politics, science, erotic life, religion-amongst which we have to choose, but with no underlying, universal rationality for the choice. The tragedy here is the tragedy of, say, the religiously minded politician (characterised in 1919 , in 'Politics as a Vocation') who is forced by the logic of political action to incur dirty hands for his or her deeds. In Weber's mind, this was dramatised by the conflict of Tolstoy versus Machiavelli. Tolstoy was all very well but politics is a nasty business, and necessarily so if we are to call it politics and not something else (Weber 1994; cf. Turner 1992). Weber's solution, in so far as there was one-though it would hardly be a tragedy if there was an actual solution-was that we should face up to this situation, meet the demands of the day and so have true 'inner distance' and 'personality' (Owen 1991).

It would of course be possible to go on with this theme of the tragic irony of modernity. One thinks too, in this context, of Tocqueville's thesis in Democracy in America that democracy-inevitable and even desirable as it may be-also runs the risk of turning into the despotism of the masses. What is gained by one necessity-the epochmaking eclipse of the aristocracy - we lose by another. In such cases, modernity turns upon itself in an ironic twist, possibly enslaving the very subjects it aims to emancipate (Tocqueville 2003, Vol. 2, Pt. 4, Ch. 6). Weber's model is, however, interestingly close to the Greek conception; not just because of the theme of the warring gods but also because Weber, as it were, performed the dramatic tensions embodied in his work and personality. As Karl Jaspers observed, Weber embodied the 'fragmentary' tendencies and tensions of modernity (Jaspers 1989, pp. 4-5). Weber attempted, as it were, to live up to the fragments. He was himself a sort of tragic drama of conflicting necessities; '... in this figure I saw, for the first time, what a Hellenic speaker must have been like' (Heinrich Wolfflin quoted in Hennis 2009, p. 174).

\section{Modernity and Political Life}

So far we have been alluding to the 'fate' of modernity - tragic or otherwise-in quite general terms. But what specifically of politics? We can invoke Weber again here since his description of the situation remains so sharp. In the 1919 'Politics as a Vocation' lecture, Weber had argued that politics had become a value-sphere in its own right; and that in so far as politics is a profession or vocation it is also a trial, an ordeal (Weber 1994, pp. 362-363). For Weber, the drama resided above all at the level of political leadership; it was the leader, the one with the specific vocation for politics, that experienced at the extremes 
the tragic irony of the times. The distinction between an ethics of conviction and an ethics of responsibility was, for Weber, internal to politics as a value-sphere; structurally, anyone engaged in politics has to negotiate these alternatives, to manage the balance - and the contradictions - between the two. Politics, Weber famously observed in 1919, was a fairly tortured business, a 'boring of hard boards' (ibid, pp. 360-362, 369; Turner 1992).

But if we are to say a little more about the tragic structuring of politics in modernity, the key witness we need here is not only Weber and his concern for the violence that is latent in all political life but also Rousseau (Merquior 1980). If anyone inaugurated the modernity of political life, it was Rousseau in The Social Contract in 1762. If we are looking for the modernity of political life, this would have to involve the idea of the self-determination of peoples; however, such peoples are to be defined; the unlocking of the aggregated will of such peoples in what Rousseau famously called the general will (Rousseau 1997).

This is in some ways an obscure idea. It hovers between a basic descriptive conception-the general will is whatever the general will is-and a normative one whereby the general will is actualised only by those who know what it should be (Bertram 2004). The idea of the general will has been maligned as romantic and populist, but in fact the very circumstances of democratic life mean that claims must surely be made in the name of some version of it. Political representatives have to be able to claim that they do in fact represent something - their constituents, the electorate, the people - but always this involves some kind of aggregation of desire; that there is a collective will out there that is somehow to be represented and promoted in, broadly, a 'hopeful', 'progressive' or somehow 'improving' way. Politics in modern states would not in fact be conceivable without a variety of just such ideas, even though Rousseau himself should not be mistaken, as he so often has been, as some kind of naive stooge of it.

This is not just to do with the well-known irony that Rousseau himself would have regarded France as just about the last place where the general will might be actualised (ibid, p. 196). It is also because Rousseau was aware of the structural not just the incidental difficulties of ever actualising it. Judith Shklar, in a brilliant article on The Social Contract, observes that the text has at least two voices running alongside each other: the egalitarian, democratic one and another one, which she calls the voice of 'dire tragedy' (Shklar 1998b, p. 263). This latter voice is most in evidence in the Third Book where Rousseau shows that government is a necessary evil but also in some contradiction to the idea of the general will since governments must corrupt society; 'the victory of the clever and unscrupulous few over the dull multitude is inevitable' (ibid, p. 273). The arts of politics, then, are ultimately doomed to failure. As Shklar puts it, 'The tragedy is that we can imagine a world better than the one we can make. We are therefore in a position to judge actuality, but not to improve it' (ibid, p. 274).

But whatever the much-debated complexities of Rousseau's own position on the matter, the problem with any set of ideals based upon the aggregation of political desire is that there is no such straightforward thing as the people (Riker 1988). Peoples are plural, not homogeneous, not singular. This, however, does not make Rousseau 'wrong'. If democratic politics are to make sense, to be present- and future-oriented, in short 'legitimate', they have to have recourse, however cynically or hypocritically, to conceptions of the people or at least the will of the collective or the political community. Yet, the people, the political community, cannot be realised because 'it' does not exist; they have, at most, to be brought into being, with all the, certainly tragic, repercussions that more or less inevitably attend such an aspiration. Peoples are aggregates but disjunct aggregates; an electorate, even a majority, is not the same thing as $a$ people.

Now, this surely implies a tragic conception of the sort we have been considering in relation to social theory generally; the clash of rival necessities - that the people must be represented but that they cannot be represented; that representation will always fall short of the will of the people simply because there is no such thing as the will of the people. The great symbol of this tragedy, the event that encapsulates it both in actuality and symbolically, has a name; it is the Terror in the French Revolution.

\section{Enlightenment and Terror}

The Terror! Surely it will be said that this is an old liberal or rather liberal-conservative, even reactionary, theme perhaps paraphrasing — and vulgarising - Edmund Burke in his Reflections of 1790 (Burke 1999). Burke's conception of tragedy was basic not ironic; the terrors of the Revolution (even such as they were in 1790) were avoidable, not part of conflicting necessities. For Burke, the Revolution was a tragedy because it need not, indeed should not, have happened. The more complex, ironic version holds that it is a tragedy precisely because it had to happen and indeed should have done so.

From early on it was recognised that the Revolution embodied a spirit that was somehow surplus to the sum of its empirical parts. Kant wrote in The Contest of the Faculties (1798): 'The revolution which we have seen taking place in our own times in a nation of gifted people may succeed, or it may fail... But I maintain that this revolution has aroused in the hearts and desires of all spectators who are not themselves caught up in it a sympathy which borders almost on enthusiasm, although the very utterance of this 
sympathy was fraught with danger...' (See Kant 1970, p. 182; Foucault 1986; Gordon 1986).

In other words, the Revolution, however badly it turned out, was-is-worth something. It was the political expression precisely of Rousseau's principle of justice and selfdetermination through something like the general will. It is what all of us who are in the slightest sense democrats can have sympathy even enthusiasm for; the noble principle if not the actual thing, since the actual thing led, as historians of the Terror tell us, to some unspeakably bad-tragic-results. Marx in a way agreed with Kant, albeit with rather typical cantankerous bluster, in effect, with the response that one cannot make omelettes without breaking eggs. But Marx's views, both of the Revolution generally and the Terror in particular, certainly changed over time (Furet 1989). Whether conceived as a transition to a bourgeois order or as the spontaneous expression of a people's will, the point was that the Revolution was a key political symbol of enlightenment.

Of course, it is easy to say that the Terror is where the Revolution went wrong; but it is just as straightforward to respond, using various kinds of argument, that the Terror was not where it all went wrong, perhaps because it was not as bad as we might think, perhaps because revolutionary activity inevitably involves violence. But we need to think about the Terror differently from the logic implied by such either/or conceptions. That is precisely where the concept of tragedy can help us.

The Terror-the Great Terror (for there were earlier episodes)_applies to the period from the Spring of 1792 when the Revolution took a radicalising turn in the context of war and internal revolt until 1794 with the downfall of Robespierre. In August 1792, with France faltering in the war against Austria and Prussia, the monarchy was overthrown; in September, there was an episode of extreme mob justice in the form of the massacre of prisoners (the September Massacres), the prisoners being regarded as counter-revolutionaries and dangerous in the context of so many revolutionaries leaving Paris and going off to war. There were popular fears of counter-revolutionary plots and demands that the enemies of the Revolution should be hunted down and eliminated. Around a year later, in June 1793, the Committee of Public Safety was established; a nasty little troika designed as an emergency executive power (Palmer 1969). Robespierre was soon in the ascendancy. The infamous Law of Suspects was passed on September 17th 1793. This defined 'suspects', supposed enemies of the revolution, in very broad terms such that just about anyone who was not a dedicated sans-culotte might qualify. Nearly a year later, another law, the $22^{\text {nd }}$ Prairial (of June 1794) widened the definition still further, and also changed the rules so that the accused were deprived of counsel, whilst relaxing any residual requirement to substantiate and verify accusations. Basically if you were accused-and it was easy to accuse-you were guilty. This was the rule of law of a particular sort; the rule of revolutionary law, but without safeguards or handrails.

In recent years, there has been some attempt if not exactly to justify the Terror as a straightforwardly 'good thing' then to put it into some context as not entirely a bad one. Sophie Wahnich's In Defence of the Terror is one of these, together with Slavoj Žižek's writings (Wahnich 2012; Žižek 2007; cf. Sagan 2001 for a different, if not very impressive, psychoanalytical take on the Revolution). Arcane Lacanianism is not, however, compulsory. Quite mundane empirical arguments can be deployed to take this sort of position. It can be observed that the state took over the role of the Terror as a means of preventing the people from doing so. As Danton reportedly said in 1793 , 'Let us be terrible in order to prevent the people from being terrible'. In that sense, the Terror was a controlled and possibly lesser evil rather than an instance of what Bacon famously described in another era as wild justice, i.e. uncontrolled, spiralling, ungovernable revenge (Lawday 2009, pp. 218-219).

It might also be argued that the Terror was a response to an emergency situation, a case of 'supreme emergency' as even liberal theory has it these days; a situation of war and revolt where national interest had to take first place over wider issues of procedural justice and the rule of law (see Walzer 2005). It has long been argued that the Terror itself was applied selectively and in that sense was not such a terrible thing as has been made out; aside from in Paris, predominantly in those areas that had been affected either by revolt (the Vendée above all) or the threat of invasion (various coastal areas) (Cobb 1964; cf. Schama 1989, p. 786). Similar to this sort of argument, though less empirically nuanced, is the more basic contention that the numbers were not that high. There is something rather gestural about the numbers game, yet it is indicative of the extent to which thinking about the Terror can be a matter of assessing degree rather than substance. Eric Hobsbawm observed that the Terror 'killed only modest numbers: perhaps a few tens of thousands' (Hobsbawm 1990, p. 5). Other estimates put it somewhat higher - usually at around 40,000 plus many more imprisoned but not executed (see works by Tackett 2015; Mathiez 1922; Furet 1981; and the comments of Schama 1989, especially referring to the Vendee, pp. 791-792). But after all, on Hobsbawm's sort of reckoning, even this is surely not that much-given what was at stake; the incarnation of revolutionary desire.

The contention here, prompted by our reflections on the ironies of tragedy, is indeed that this either/or debate about the Terror rather misses the point. The Terror was in fact not just a question of numbers but was a substantive political tragedy, and one-for instance, in our current era of populisms of a very different sort-that has unquestionable resonance down to our own times. Simon Schama identifies 
a number of factors, some endogenous, but the final inevitability of what occurred seems, on the balance of his complex argument, to have been exogenous, ensured by the threat of foreign insurgency and impact (Schama 1989, p. 752). More generally, on Schama's argument, if the Revolutionor at least the Terror-was a tragedy, this was consequent upon two necessities coming into conflict, but necessities that were incidental to each other; the demand for equality and justice, and the demand for patriotism in the context of war-and patriotism won out, ultimately in the distorted form of the Terror (Schama 1989, p. 755). Schama's is a striking argument and he is appropriately harsh with those historians who have sought to downgrade the Terror (ibid, $\mathrm{p}$. 755). For him, the key appears to be the inevitability of the military state, that 'militarized nationalism' founded on the 'dictatorship of virtue'; the brutally anti-federalist dreamand implementation - of undifferentiated power (ibid, pp. $767,856,858)$. Now, this disaster, this tragedy, was not incidental to the Revolution, but fundamental to it. In fact, what was at stake here was the tragedy of the popular will itself and its inevitable impossibility of actualisation. As Schama shows, there are two sides to the founding of universal citizenship in the State; on the one hand the citizen with rights, on the other hand the citizen that is subject to the state (ibid, p. 858). If tragedy lurked here, it was the very idea that there can be unmediated power at all, that the general will can be constitutively embodied in the people, the nation, and then (perhaps inevitably) even in one person-Robespierre (see on this Lefort 1986, p. 82). It was a tragedy to do with the perhaps inevitable yet, for all that, impossible composition of the people.

Francois Furet captures all this nicely by emphasising the colossal importance in the revolution of the fear of plots (Furet 1981). Perhaps the paranoia was understandable, even necessary; for of course there really were foreign agents and foreign powers and those who resisted the course of the revolution. And that is the point. It is not as if the Terror was straightforwardly avoidable given the very structure of-necessary-revolutionary ideology. Perhaps it was avoidable in the particular form it took, yes, but the fact is that the people cannot be constituted without doing some kind of violence (even if only symbolic) to those deemed to be outside the people. Revolutionaries and citizens have to be made and that entails un-making those who will not conform. It is the tragic potential, as it were, that resides within that great necessity of our time- - the popular mass democracy of the general will. In Furet's terms, ideology simply came to be mapped without remainder upon politics. One might allude here to the breakdown of anything resembling the rule of law, but in fact what happened was that the rule of law became immediately synonymous with the demands of the populist, patriot state. Law became inseparable from politics. The law was used as a direct instrument of power.
Anyone was guilty who lacked sufficient revolutionary fervour; the norm became extremist activism, what Lefort calls the 'phantom of the interminable'-interminable vigilance, interminable activism (Lefort 1986, p. 113). Under such conditions, there could be no mundane, everyday life, no space for anything but the direct application of ideology, the saturation of everything by compulsory political fervour.

Furet is right to insist that this is not simply about what he calls the 'theory of circumstances', the immediate circumstances of emergency in the face of war. It was a logic endogenous to the Revolutionary spirit itself, embodied for instance in Saint-Just's ludicrous Spartanism or in Robespierre's terrifyingly reductive 'doctrine of virtue' (Schama 1989, p. 767). It is well known that the French Revolution was driven in part by fantasies of the ancient citystate, and that Benjamin Constant did much to found modern liberalism in 1819 by critiquing that association (Constant 1988; Williams 1995b). But as Paul Veyne showed, the best analogue of the ancient Greek state is not that of 'ancient Liberty' in Constant's sense, but something more like a revolutionary sect; a paranoid, interminably activist organisation permanently cutting off its enemies, constantly harassed by imaginary plots and takeovers (Veyne 2005). Contrary to Constant's argument, this made the French revolutionary state remarkably compatible with that of Sparta or, albeit to a lesser extent, Athens. The tragedy was not that, in Constant's terms, the one model did not fit the other; but that to make the models fit, the Terror was, as it were, necessary-not simply as an incidental reaction to 'circumstance' but as part of integral, endogenous revolutionary logic. The people-the general will—do not pre-exist their construction out of Terror because Terror was what separated, as it were, the wheat from the chaff and because Terror galvanised, or was meant to galvanise, the people into virtue. That was Robespierre's motto- the rule of virtue to the cost of everything else (Scurr 2007).

\section{Reluctant Liberalism?}

There is a further twist to this sense of tragedy here. The tragedy is not just the fact of the Terror itself, the tragedy of the impossibility of realising the general will, but also the necessary consequence of that, which is to say the necessity of a certain anti-idealistic realism about the inevitabilities of power. In other words, the cure is also in a sense tragic in its necessity, lying in the dilution and diminution of political possibility. The outcome of this is what Judith Shklar bundled up in the terminology of the 'liberalism of fear'; the necessity of tolerating those we might politically dislike, of relying on intermediate powers, the rule of law and representative principles, and-whatever our political idealssimply 'putting cruelty first' (Shklar 1964, p. 5; cf. Shklar 
1998a; Shklar 1984: 7-45). Rousseau is persistently relevant here. What Rousseau himself consistently opposed was any breaking up of the general will or its limitation by intermediate powers. It is a commonplace that Rousseau himself was sceptical about the general will operating in anything but small states; large states, he thought, would necessarily have to be dictatorships of a sort. But in either case, what Rousseau opposed at least in principle was the exercise of intermediate powers, the separation of powers (see Schmitt 2014, p. 101; cf. Bertram 2004, pp. 171-172) —in short, Rousseau's perspective was opposed to what we could shorthand as the Montesquieu principle, the principle of 'moderated' power, the breaking up of power into different parts that might balance each other; differentiated power (Montesquieu et al. 1989).

Montesquieu, predating Rousseau, effectively predictedand answered-him. For Rousseau, at least ideally (although, certainly, Rousseau himself was well aware of the difference between the idea and what was possible), power had to be a plenitude in the sense of a kind of 'expressive whole'; for Montesquieu, on the other hand, any aspiration that relied upon making power into a singular, unilinear plenitude led to despotism. Montesquieu was of course an aristocrat and his model of parlements as intermediate powers was based on the idea of aristocratic representation, there to balance the king - an idea of balance that had been eclipsed under the rule of Louis XIV. Aristocratic parlements mediated power; they balanced the king and they balanced the people (Furet 1981, p. 44). Rather than being antiquated, this aristocratic liberalism became essential to later versions of liberalism itself-for parliamentary power, the rule of law are powers that are, in essence, invested in specialist, or elite bodies (Manent 1996). The tragedy in this rather secondary sense was that some kind of fall-back to the Montesquieu position-one that if it scarcely lacked all conviction was certainly devoid of passionate intensity-was necessary if either Saint-Just's retroSpartan state, the dictatorship state, was to be avoided. And indeed with the fall of Robespierre, France did revert-or progress? - to something like a liberal state, the Directory, based on something like the rule of law, if only briefly; for after that came, of course, the 18th Brumaire, and Napoleon.

After Rousseau, a more sceptical form of moderation or liberalism, here associated with Montesquieu's 'system of political liberty', has to be seen as a fall-back, a compromise, a reluctant liberalism and not as an ideological triumph of any sort. The Montesquieu principle does not, anyway, lead to the kind of liberalism embraced by the triumphalism of a Hayek or a Fukuyama. If anything it is the embrace of the lesser evil; some amount of chaos is always preferable to indivisible power. Power, for better or worse, is best divided. Unmediated power leads to despotism, indeed it is despotism. The point is that if we want to avoid the kind of political tragedy embodied in the Terror we are condemned to liberalism at least of a minimalist, political sort, as a claim upon us; that is, as a critical claim not necessarily as the source of a comprehensive ideology- (all sorts of political perspectives can be added to what Shklar (and Bernard Williams) insist is the basic universalism of this sort of liberalism (Shklar 1998a; Williams 2005). We are thus 'condemned' to the moderation of power, to representatives, to the division and balancing of powers, to the so-called rule of law, political fudge and compromise, even political hypocrisy and so on. Preventing cruelties is not usually a very romantic business; it is much more exciting to put cruelty a distant second to political passion, desire, the general will, the future, passionate intensities of all kinds. If this kind of liberalism represents, as itself a kind of necessity, and arguably a universalist one, a tragedy of a particular sort, it is only as a much lesser tragedy to what happens when there are attempts to impose what is taken to be the general will in immediate terms.

Nevertheless, it is important not to forget that some such aggregating of political desire is nonetheless integral to democracy. Those latter-day fantasies of the general will-embodied in populisms of various kinds - are not external blemishes on political reality but embody the necessary fantasy (which, however necessary, is still a fantasy) of unmediated power; that the people can speak directly and have a voice, that the collective will can be directly actualised in politics. But there is no uniform, unidirectional collective will; and we are still learning that lesson. Populists of whatever political hue, left or right, are populists in so far as they exclude the messy reality of those who are not the 'people' (Molyneux and Osborne 2018). As Michael Mann showed some time ago there is indeed a dark side to democracy; the demos seeks homogeneity (Mann 1986). But if democracy were just a 'bad thing' then that would not be tragedy. It would just be a question of getting rid of democracy; something that would not only be reactionary but obviously counter to all the achievements that have been made in political life since the Enlightenment. It is more that the authentic democracy embodied in the idea of the general will is both necessary as a demand yet not possible; it is the object of Kantian hope, of Foucault's kind of enlightenment perhaps, but not a finished, settled state since we will never get there. The political tragedy is, in this sense, that there can be no end of history, but that also happens to be a good thing.

\section{Politics, Inauthenticity, Horror}

What typically goes by the name of politics itself can be regarded as a sort of messy compromise option. We have politics - as much as we can stand - precisely to stand in the way of power. This makes contemporary politics a sort of laboratory of moral hazard, difficult choices and conflicting obligations. Politics is an exemplary arena of action precisely for the dilemmas and contrasting necessities-and so tragic compromises-that it tends to throw up if just in an ordinary way. 
As Williams writes, the interesting ethical issues in politics tend to come down not to whether politicians are criminals but as to whether or not they are crooks (Williams 1973, p. 55; Osborne 2014). Can we see genuine modern analogues to Greek tragedy in this sense? Classics of modern drama that might fit the description of political consequences attendant upon the conflict of the individual with the wider social structure might come from Ibsen's Public Enemy or even Coriolanus; but there is an example that exactly overlaps our own theme of the Terror in an obvious and striking way and that is Georg Büchner's Danton's Death of 1835 (Büchner 1993). If it is worth briefly alluding to this sort of tragedy, it is because literary tragedy is, as it were, a means of reflecting on tragedy itself, actual tragedy, as a means of laying 'its fictional horrors before us in a way that elicits attitudes we cannot take towards real horrors' (Williams 2008, pp. 58-59).

The tragedy of Danton's Death is at one level simply the inevitability of Danton's succumbing to revolutionary violence and fanaticism, Danton's Tod of the title; but his demise actually comes earlier than that-it emerges prior to Danton's actual death in his fatalism in the face of what confronts him. It is not an anti-revolutionary play; Büchner himself was, amongst other things, a revolutionary activist, and the Revolution has the status precisely of a kind of necessity in his pages. Yet what emerges is a strong sense of the inauthenticity, the play-acting element entailing both posturing and compromise, of revolutionary behaviour in particular but also of ordinary political machination in general. Perhaps a certain lack of conviction or of 'enthusiasm' is even necessary for a moderate political order. Indeed, the only authentic types in Danton's Death are Saint-Just and Robespierre, the extremists of virtue and main proponents of Terror. Moderate political life in so far as it is a life of petty, unromantic machination and compromise condemns its protagonists to basic kinds of inauthenticity of this sort. But to be so condemned is, paradoxically, also to be authentically engaged in politics, precisely as Weber saw. Danton, in Büchner's version, is not just disillusioned with politics; his own tragedy is inherently to do with the acknowledgement of its inauthenticity. And the presentation of Danton by Büchner as the moderate in contrast to Robespierre's (and Saint-Just's) fanatic does register precisely something of what has been invoked here as the reluctant necessity of something like a basic kind of sceptical liberalism; the fact that we are condemned to it rather than it being something we could ever embrace wholeheartedly with passion or intensity. The Danton of Danton's Death simply gives up in this respect and goes more or less resignedly to the guillotine. If Danton's more moderate way or at least the moderation he comes to espouse (and especially, of course, in the context of the irony that he was in the first place one of the main instigators of the Terror itself) leads to less bloodshed, it stands no chance of prevailing in the heat of revolutionary fervour; and Danton in the play appears veiled in regret for his role in the September massacres and other aspects of the Revolutionary tragedy. The poor have got no less poor and certainly - in spite of Robespierre and the truly ghastly Saint-Just-no more virtuous; the revolutionary bloodlust has been served, but that is about all.

Alongside this inauthenticity, indeed a component of it, there is a certain kind of horror. In some mesmerising pages, Stanley Cavell attempted to invoke the essence of tragedy itself not as the occurrence of awful things-what he calls terror-but as a kind of sensibility, the horror at oneself as to what one has become (Cavell 1979, 418-425). For Cavell, this is to acknowledge the horror that we are human, which is to say the horror that we might not be what we take ourselves to be, but outsiders, even monsters; 'the perception of the precariousness of human identity... the perception that it may be lost or invaded, that we may be or become something other than we are, or take ourselves for...' (ibid, pp. 418-419). This kind of tragedy is the horror that one can be inhuman, even unrecognisable to oneself. As Montaigne wrote: 'Nature herself, I fear, attaches to man some instinct for inhumanity' (Montaigne 1958, p. 383). This predicament is not exclusive to political life, but is surely peculiarly dramatised by it. Certainly, what Büchner's Danton experiences is horror not terror; horror at the circumstances of his own existence and what he has become as a result of that kind of existence. In Büchner's treatment, Danton does not fear the guillotine; in fact he all but wills it. This is not mere resignation, but a sense of horrified justice for what he has become.

This of course registers a very different topos of tragedy from that of the ancients. Here, tragedy is not ineluctable fate, is not tied to the will of the Gods or the inevitable destiny of the city; tragedy here is individualised and is a risk pertaining to the exercise of responsibility itself, and especially political responsibility. Like all true tragedy there is no solution to it, or a way out.

Acknowledgements Thanks to Samantha Ashenden and James Brown for their comments and for setting up the symposium on tragedy in relation to social and political thought where this paper originated. The piece was written during a period of research sponsored by the Leverhulme Trust. I also wish to thank Gabriel Osborne for sharing his expertise on these themes with me, and two referees from this journal for their detailed and incisive comments that did much to improve the paper.

Open Access This article is licensed under a Creative Commons Attribution 4.0 International License, which permits use, sharing, adaptation, distribution and reproduction in any medium or format, as long as you give appropriate credit to the original author(s) and the source, provide a link to the Creative Commons licence, and indicate if changes were made. The images or other third party material in this article are included in the article's Creative Commons licence, unless indicated otherwise in a credit line to the material. If material is not included in the article's Creative Commons licence and your intended use is not permitted by statutory regulation or exceeds the permitted use, you will need to obtain permission directly from the copyright holder. To view a copy of this licence, visit http://creativecommons.org/licenses/by/4.0/. 


\section{References}

Adorno, Thedor \& Horkheimer, Max (1944) Dialectic of Enlightenment, London: Routledge.

Beck, Ulrich (1992) Risk Society, Cambridge: Polity.

Bertram, Christopher (2004) Rousseau and The Social Contract, London: Routledge.

Büchner, Georg (1993) Complete Plays and Other Writings, London: Penguin.

Burke, Edmund (1999) Reflections on the Revolution in France [1790], Select Works of Edmund Burke volume 2, Indianapolis: Liberty Fund.

Cavell, Stanley (1979) The Claim of Reason: Wittgenstein, skepticism, morality and tragedy, Oxford: Oxford University Press.

Cobb, Richard (1964) Terreur et Subsistances, Paris: Clavreuil.

Connerton, Paul (1980) The Tragedy of Enlightenment, Cambridge: Cambridge University Press.

Constant, Benjamin (1988) The liberty of the ancients compared with that of the moderns [1819], in Political Writings, Cambridge: Cambridge University Press.

Foucault, Michel (1986) Kant on Enlightenment and revolution, Economy and Society, 15, 1, 81-96.

Furet, François (1981) Interpreting the French Revolution, Cambridge: Cambridge University Press.

Furet, François (1989) Marx and the French Revolution, trans. D.K. Furet, Chicago: Chicago University Press.

Gordon, Colin (1986) Question, Ethos, Event: Foucault on Kant and Enlightenment, Economy and Society, 15, 1, 71-87.

Heidegger, Martin (2013) The Question concerning technology [1954], in The Question Concerning Technology and other essays, tr. W. Levitt, New York: Harper.

Hennis, Wilhelm (2009) Politics as Practical Science, tr. K. Tribe, London: Macmillan.

Hobsbawm, Eric (1990) Echoes of the Marseillaise, London: Verso.

Jaspers, K. (1989) Max Weber, a commemorative address (1920), in Karl Jaspers on Max Weber, ed. J. Dreijmanis, New York, Paragon

Kant, Immanuel (1970) Political Writings, Cambridge: Cambridge University Press.

Lefort, Claude (1986) Essais sur le Politique, Paris: Seuil.

Manent, Pierre (1996 An Intellectual History of Liberalism, Princeton NJ: Princeton University Press.

Mann, Michael (1986) The Dark Side of Democracy, Cambridge: Cambridge University Press.

Mathiez, Albert (1922) The French Revolution, London: Williams and Norgate.

Merquior, José Guilherme (1980) Rousseau and Weber, London: Routledge.

Molyneux, Maxine \& Osborne, Thomas (2018) Populism - a deflationary view, Economy and Society, 6, 1, 1-19.

Montaigne (1958) Of cruelty [1578-80], in The Complete Works, tr. R. Frame, New York, Everyman.

Montesquieu, Charles-Louis de Secondat, Baron de La Brède et de (1989) The Spirit of the Laws, trans. A. Cohler, B. Miller \& H. Stone, Cambridge: Cambridge University Press.

Osborne, Thomas (2014) Between cynicism and idiocy: deflationary realism and grubby fingernails in politics, European Journal of Cultural and Political Sociology, 1, 2, 141-157.

Owen, D. (1991) Autonomy and 'inner distance': a trace of Nietzsche in Weber, History of the Human Sciences, 4, 1, 79-91

Palmer, Robert R. (1969) Twelve Who Ruled: the year of the Terror in the French Revolution, Princeton: Princeton University Press.

Riker William H. (1988) Liberalism against Populism: A Confrontation Between the Theory of Democracy and the Theory of Social Choice, Long Grove, IL: Waveland.
Rousseau, Jean-Jacques (1997) The Social Contract and other Later Political Writings [1762], trans. V. Gourevitch, Cambridge: Cambridge University Press.

Sagan, E. (2001) Citizens and Cannibals, New York: Rowman and Littlefield.

Schama, S. (1989) Citizens: a chronicle of the French Revolution, London: Viking.

Schmitt, Carl (2014) Dictatorship [1921], Cambridge: Polity.

Scurr, Ruth (2007) Fatal Purity: Robespierre and the French Revolution, London: Viking.

Shklar, Judith (1984) Ordinary Vices, Cambridge, Mass., Harvard University Press.

Shklar, Judith (1964) Legalism: law, morals and political trials, Cambridge, Mass: Harvard University Press.

Shklar, Judith (1998a) The liberalism of fear, in Political Thought and Political Thinkers, Chicago: University of Chicago Press.

Shklar, Judith (1998b) Rousseau and The Social Contract, in Political Thought and Political Thinkers, Chicago: University of Chicago Press.

Shklar, Judith (2019) On Political Obligation (ed. S. Ashenden \& A. Hess), New Haven, Yale University Press

Tackett, Timothy (2015) The Coming of the Terror in the French Revolution, Cambridge, Mass: Harvard University Press.

Tocqueville. Alexis de (2003) Democracy in America [1835/1840], trans. G. Bevan, London: Penguin.

Turner, Charles (1992) Modernity and Politics in the Work of Max Weber, London: Routledge.

Veyne, Paul (2005) Did the Greeks know democracy? Economy and Society, 34, 2, pp. 322-345.

Wahnich, S. (2012) In Defence of the Terror, London: Verso.

Walzer, Michael (2005) Emergency Ethics, in Arguing About War, New Haven: Yale University Press.

Weber, Michael (1991a) Science as a Vocation [1919], in From Max Weber, ed. H. Gerth \& C.W. Mills, London: Routledge.

Weber, Max (1991b) Religious rejections of the world and their redirections [1915], in From Max Weber, ed. H. Gerth \& C.W. Mills, London: Routledge.

Weber, Max (1992) The Protestant Ethic and the Spirit of Capitalism [1904-5], London: Routledge.

Weber, Max (1994) The profession and vocation of politics [1919], in Political Writings, ed. P. Lassman, Cambridge: Cambridge University Press.

Williams, Bernard (1973) Politics and moral character, in Moral Luck, Cambridge: Cambridge University Press.

Williams, Bernard (1985) Ethics and the Limits of Philosophy, London: Fontana.

Williams, Bernard (1995a) Shame and Necessity, Berkeley, CA: University of California Press.

Williams, Bernard (1995b) Saint-Just's illusion, in Making Sense of Humanity, Cambridge: Cambridge University Press.

Williams, Bernard (2005) In the Beginning was the Deed, Princeton: Princeton University Press.

Williams, Bernard (2008) The Women of Trachis: fictions, pessimism, ethics, in The Sense of the Past, Princeton: Princeton University Press.

Žižek, Slavoj (2007) Robespierre: Virtue and Terror, London: Verso.

Publisher's Note Springer Nature remains neutral with regard to jurisdictional claims in published maps and institutional affiliations.

Thomas Osborne is Professor of Social and Political Theory at the University of Bristol, UK. His current interests centre on the history of vitalism in social and philosophical thought, and also on aspects of political theory and political ethics. 